\title{
New Directions for the Law of the Workplace
}

\author{
Paul Weiler ${ }^{\dagger}$ and Guy Mundlak ${ }^{\dagger \dagger}$
}

\section{INTRODUCTION ${ }^{1}$}

Professors Getman and Marshall's in-depth account of the paperworkers strike in Jay, Maine ${ }^{2}$ vividly portrays the legal and economic blows that have been suffered by workers in the United States over the last fifteen years. The authors put a badly-needed human face on the dry statistics that we see on the business pages and on the technical jargon we read in the law reports regarding labor.

The events in Jay-like those in countless other union and nonunion workplaces across the country-evidence a major shift in the nation's direction with respect to economic policy. Bill Clinton won the presidency in November, 1992, in part because the electorate believed his (and Ross Perot's) message that the country needed a fundamental change in economic policy. The new President, together with his Secretary of Labor, Robert Reich, have put American workers-this country's human, not financial, capital-at the forefront of their agenda for economic rejuvenation. ${ }^{3}$

The principal focus of the forthcoming policy debate will be upon major changes in the way this country educates, trains, deploys, and motivates labor-a resource that is crucial to the nation's competitive standing. Legal change is a second-order priority. But the fact that the law is less important

$\dagger$ Professor, Harvard Law School. After this Comment was first written, Professor Weiler was asked to serve as Chief Counsel to the President's Commission on the Future of Worker-Management Relations. The views expressed in this Comment are, however, those of Professor Weiler and Mr. Mundlak alone.

t† S.J.D. Candidate, Harvard Law School.

1. This Comment draws upon views that were developed in much more detail in PAUL C. WEILER, GOVERNING THE WORKPLACE: THE FUTURE OF LABOR AND EMPLOYMENT LAW (1990) [hereinafter WEILER, GOVERNING THE WORKPLACE], and then elaborated upon in Paul C. Weiler, Governing the Workplace: Employee Representation in the Eyes of the Law, in EMPLOYEE REPRESENTATION: ALTERNATIVES AND FUTURE DIRECTIONS (Bruce Kaufman and Morris Kleiner eds., forthcoming 1993) [hereinafter Weiler, Eyes of the Law]. In this brief Comment, we will refer only to the more recent scholarly works that have appeared and upon which we draw.

2. Julius G. Getman \& F. Ray Marshall, Industrial Relations in Transition: The Paper Industry Example, 102 YALE L.J. 1803 (1993).

3. See Robert B. ReICH, THE WORK OF NATtONS: PREPARING OURSELVES FoR 21ST Century CAPITALISM 3, 8 (1991). Two other books in the same vein, both of which appeared with President Clinton's endorsement during the 1992 presidential election campaign, are BARRY BLUESTONE \& IRVING BLUESTONE, Negotiating THE FutURE: A LABOR PERSPECTIVE ON AMERICAN BUSINESS (1992); RAY MARSHALl \& MARC TUCKER, THINKING FOR A LIVING: WORK, SKILlS, AND THE FUTURE OF THE AMERICAN ECONOMY (1992). 
does not mean that it is unimportant. A voluminous body of labor and employment law has evolved over the last half-century which permeates the workplace, influencing both the way we organize production and the way we divide up what we hope will be an expanding pie among those who have contributed to it. The lesson of the past decade, and of Getman and Marshall's piece, is that our current legal arrangements are far from ideal for either of these tasks.

In this Comment, we examine some of the economic and legal trends that support Getman and Marshall's general conclusions and then present our views on how policymakers should respond to these conclusions. We argue that the fundamental deficiency in the law of the American workplace is that it denies ordinary employees effective representation of their interests in their employers' key decisions. The strike replacement issue that the authors bring to life epitomizes the current weakness of traditional union representation and collective bargaining. However, another crucial issue in the law of the workplace, displaying the representation problem from a different angle, was illustrated by a long-awaited decision issued by the National Labor Relations Board at the end of 1992. In the Electromation decision, ${ }^{4}$ the NLRB refused to remove the legal cloud cast by the New Deal Wagner Act over nonunion employee participation plans-an increasingly popular device under which the employer's personnel department bears responsibility for seeing that employees' views and interests are taken into account. These and a host of other legal issues will inevitably claim the attention of the new Administration and the new Congress as the two branches of government seriously rethink what the American workplace and its law should look like in the twenty-first century.

\section{TRENDS IN THE WORKPLACE}

\section{A. Economic Malaise}

Through their narrative of the events in Jay, Maine, ${ }^{5}$ Getman and Marshall depict how many employers still favor a low-wage, managerial control strategy over the high-wage, joint control strategy. Indeed, American employees-most of whom work outside the executive suite-have ample reason to be unhappy with the performance of those in charge of both private business and public

4. Electromation, Inc. and Teamsters Local 1049, No. 25-CA-19818, 1992 WL 386692 (N.L.R.B. Dec. 16,1992) (finding that nonunion employee committees were not simply "communication devices" but labor organizations and that Electromation's involvement with the committees constituted domination and interference).

5. Getman \& Marshall, supra note 2, at 1814-45. 
policy. The following statistical trends summarize what such performance has done to workers over the last fifteen years. ${ }^{6}$

Hourly earnings of the average employee have declined significantly in real terms since the late 1970's, something that has not happened for any extended period since the Depression. ${ }^{7}$ While it is true that the annual income of the average family has risen modestly during that same period, ${ }^{8}$ the reason for that increase is that the average person works substantially more hours per year at a somewhat lower hourly wage rate. ${ }^{9}$ In spite of the fact that full-time male employees have been working more hours (with less paid time off), they account for a smaller proportion of the aggregate increase in workload, because their participation in the labor force has been decreasing. ${ }^{10} \mathrm{~A}$ much larger share is due to the influx of women into the workplace as full-time and parttime workers. While some feminists, as well as Reaganites, may have celebrated the "Great American Job Machine" of the 1980's for expanding women's opportunity to claim a fairer share of paid employment, most working women did not join the workforce to enjoy the luxury of an upperlevel executive or professional job with its exciting challenges and ample perquisites. Like their male counterparts, many working women endeavored to juggle the competing demands of job and child-rearing not only because they were able to, but because they had to, just to keep their families' heads slightly above water. ${ }^{11}$

6. The major source for the factual claims we will make in this section is LAWRENCE MISHEL \& JARED BERNSTEIN, THE STATE OF WORKING AMERICA 1992-1993 (forthcoming 1993). Other sources include MICHAEL DERTOUZOS ET AL., MADE IN AMERICA 1-22 (1989) (reporting a decline in productivity); JULIET B. SCHOR, THE OVERWORKED AMERICAN: THE UNEXPECTED DECLINE OF LEISURE (1991) (revealing a rise in hours worked by both men and women); Frank Levy \& Richard J. Murnane, U.S. Earnings Levels and Earnings Inequality: A Review of Recent Trends and Proposed Explanations, 30 J. ECON. LIT. 1333 (1992) (reporting an increase in earnings inequality since 1979).

7. See MISHEL \& BERNSTEIN, supra note 6, at 134-37. This trend is not simply a matter of takehome pay being depressed because employers had to make sharply greater contributions for employer benefits, whether privately or publicly provided. Though both payroll taxes and fringe benefit payments have increased modestly in real terms (with pension contributions declining significantly to make room for spiraling health care premiums), total employer payments per hour have dropped considerably during the last fifteen years. See, e.g., id. at 135, 137 (noting that cost of fringe benefits did not rise between 1977 and 1989 , while hourly wages declined by $0.7 \%$ per year from 1979 to 1989 for $80 \%$ of the workforce).

8. Id. at $35-36$.

9. See SCHOR, supra note 6, at 24-34 (estimating that average employed person is now on job an additional 163 hours per year, and that more women and teenagers are entering paid workforce); id. at 8081 (noting steady reduction in hourly rates of pay although wages of salaried workers as a group have not declined).

10. See id. at $24-28$ (finding $11 \%$ drop in male paid employment from 1948 to 1987 , and that men are working 98 more hours per year while women are working 305 more hours per year).

11. However, few American firms have tried to help workers resolve the conflict between work and home by providing on-site child care, work-sharing programs, or flexible working hours. See generally SHEILA B. KAMERMAN \& ALFRED J. KAHN, THE RESPONSIVE WORKPLACE 187-216 (child care), 226-46 (discussing time off and flexibility) (1987); Nancy E. Dowd, Work and Family: The Gender Paradox and the Limitations of Discrimination Analysis in Restructuring the Workplace, 29 HARV. C.R.-C.L. L. REV. 79, 96-105 (noting, for example, that only $15 \%$ of workers have a flexible schedule option) (1989); Felice N. Schwartz, Women as a Business Imperative, HARV. Bus. REV., Mar.-Apr. 1992, at 111-12. 
Unquestionably, part of this earnings decline is attributable to the much lower rate of productivity growth we have enjoyed since the OPEC oil crisis of $1973 .^{12}$ Young people who are now entering the workforce face a much bleaker economic prospect than their parents who rode the wave of nearly $3 \%$ annual productivity growth that occurred between the late 1940's and early 1970 's. ${ }^{13}$

Yet slower growth in productivity will not explain the absolute decline in average earnings. ${ }^{14}$ That unhappy trend is best explained by the sharp increases in wealth and income inequality that have occurred since the late 1970 's. ${ }^{15}$ A significant share of these increases have resulted from the widening gap between earnings received by upper and middle or lower-level job holders. ${ }^{16}$ Those who work as what Reich calls "symbolic analysts"17 (e.g., doctors, lawyers, engineers, investment bankers, research scientists, and management consultants) fared quite well throughout the 1980's, while those employed in either "routine production" (both traditional assembly line manufacturing and contemporary computer data entry) or provision of "inperson services" (retail sales, secretarial, janitorial, child care, or security) did poorly. ${ }^{18}$

But most income inequality has occurred because labor and capital have garnered unequal portions of the economic pie. While real earnings from work dropped steadily throughout the 1980 's, the annual return on equity capital (combining earnings and growth) was more than double the rate of inflation. ${ }^{19}$ One product of the Wall Street boom was that, even though American business' contribution to American well-being paled by comparison to that of Japanese or European firms, ${ }^{20}$ American executives were rewarded at far higher rates of compensation than their foreign counterparts because of the way in which their companies' stock were soaring on the stock market. ${ }^{21}$

\section{B. The Failure of Labor Law}

There is no question that the American economy has been buffeted by a number of major dislocations, domestic and international, over the last two

\footnotetext{
12. See DERTOUZOS, supra note 6, at 23-35.

13. See Bluestone \& Bluestone, supra note 3, at 36-37; PeTER DOERINGer, TuRBulenCE IN THE WORKPLACE 29-37 (1991).

14. See Mishel \& BERnStein, supra note 6 , at 159.

15. Id. at $43-69$.

16. Id. at $137-41$.

17. See REICH, supra note 3 , at $171-184$.

18. Id. at 196-207; MISHEL \& BERNSTEIN, supra note 6, at 43-69, 137-44.

19. See Burton G. MalkiEl, A RANDOM WALK Down WALl STREet 325 (5th ed. 1990) (from 1980 through 1989, though annual rate of increase in Consumer Price Index (CPI) was 5.7\%, compound rate of return on common stocks was $17 \%$, and on bonds was $10 \%$ ).

20. See, e.g., Dertouzos supra note 6, at 33-35 ("Producers in Europe and Asia are winning a large share of the U.S. market at the same time that U.S. manufacturers are losing their export markets.").

21. MISHEL \& BERNSTEIN, supra note 6, at 203-05.
} 
decades. But what is disturbing about the aggregate trends noted above is that those economic groups that began the 1980's well off did even better during that decade, while middle and lower income families fared poorly. The 1980's provide graphic testimony about how weak are our institutions for representing the interests of ordinary workers.

One important source of such institutional weakness is the failure of our labor law to protect the traditionally favored instrument of employee representation-free collective bargaining through independent unions of the employees' own choosing. ${ }^{22}$ Under the auspices of the New Deal labor law policy, union representation of the private nonagricultural work force (those employees guaranteed this right by National Labor Relations Act) soared to nearly $40 \%$ by the mid-1950's. ${ }^{23}$ From that base, collective bargaining strongly influenced employment conditions for nonunion staff at unionized firms or at nonunion firms in largely unionized industries. Collective bargaining not only established for the first time a measure of job security and workplace due process, but it also generated significant premiums in wages and benefits. ${ }^{24}$ These employee gains were financed to some extent by aboveaverage profits earned by firms operating in protected product markets, and to some extent by forcing management to deploy its work force more productively to compete with firms with lower labor costs. ${ }^{25}$

Notwithstanding these employee gains from union membership, however, the size of unions peaked in the 1950's and union density began to decline relative to an expanding work force. ${ }^{26} \mathrm{By}$ the late 1970 's, private sector union membership was dropping sharply in absolute size and even more steeply in relative terms. ${ }^{27}$ At present, private sector union membership is approximately $12 \%$ of private employment, roughly the level it was before the NLRA was enacted in $1935 .{ }^{28}$ Unless an unexpected turnaround occurs, by the beginning of the twenty-first century, less than $10 \%$ of private sector employees will have

22. See WeILER, GoverNiNG THE WORKPLACE, supra note 1, at 104-18; see also David G. Blanchfiower \& Richard B. Freeman, Unionism in the United States and Other Advanced OECD Countries, 31 INDUS. REL. L.J. 56, 56 (1992) (referring to unionism as "traditionally the principal worker institution under capitalism"); Gary N. Chaison \& Joseph B. Rose, The Macrodeterminants of Union Growth and Decline, in THE STATE OF THE UNIONS 3, 5, $20-22$ (George Strauss et al. eds., 1991) ("The legal environment for collective bargaining has been shown to be an important determinant of union growth and decline because of the manner in which it regulates union recognition and the retention of union members.").

23. See Chaison \& Rose, supra note 22 , at 4.

24. See Blanchflower \& Freeman, supra note 22, at 64-67; see also BLUESTONE \& BLUESTONE, supra note 3 , at 55-59 (noting that union benefits were ultimately diffused to the unorganized sector).

25. See Richard Freeman, Is Declining Unionization of the U.S. Good, Bad, or Irrelevant?, in UNIONS AND ECONOMIC COMPETITIVENESS 144 (Lawrence Mishel \& Paula B. Voos eds., 1992) ("Unions and collective bargaining change work relations by ... providing management with information about plantlevel operations, increasing productivity ....").

26. Id. at 143 (indicating generally that 1950 's were the boom era for unions and that union density declined in 1970's and 1980's).

27. Id.

28. See Blanchflower \& Freeman, supra note 22, at 58-59. 
their interests represented through collective bargaining, and unionism will be largely isolated in a number of aging industrial ghettos. ${ }^{29}$

Many scholars have considered the possible causes of the decline in the United States of private sector unionism ${ }^{30}-$ a phenomenon that stands out even more starkly when compared to the substantially larger union presence in the public sector in this country, and in the private sector in other countries. ${ }^{31}$ Unquestionably, the economic devastation inflicted by international competition on such union strongholds as auto and steel in the late 1970's and early 1980's was a major source of actual membership losses. ${ }^{32}$ But devastation in these industries does not explain why employees in such fast-growing business sectors as computer manufacturing or financial information processing have not been attracted by collective bargaining's demonstrated ability to deliver higher compensation, better protection, and greater participation in those industrial sectors where it was strong. ${ }^{33}$ Many commentators assume that collective bargaining is an institution primarily suited for male, blue-collar, production workers in the goods-producing industries that were the bastion of unionism in its heyday of the 1950 's. ${ }^{34}$ The great strides that unions made among schoolteachers and nurses in the 1970's and 1980's belie that assumption, however, for these unions consisted of predominantly female, white-collar workers in the service sector (albeit the public or non-profit sector). ${ }^{35}$

We believe that an important reason why workers in private, for-profit sectors have been reluctant to unionize is that employers in these sectors have adopted and pursued a strong union avoidance policy. This union-free strategy

29. See generally Gary Chaison \& Dileep Dharale, A Note on the Severity of the Decline in Union Organizing Activity, 43 INDUS. \& LAB. REL. REv. 366, 371-72 (noting extreme improbability that unions could recruit members needed to maintain the $12.9 \%$ density rate of 1988) (1990); see also WEILER, GOVERNING THE WORKPLACE, supra note 1, at 8-10, n.11.

30. See WEILER, GOVERNING THE WORKPLACE, supra note 1, at 105-18 (and references cited therein); Chaison \& Rose, supra note 22, at 36-40; Robert J. LaLonde \& Bernard D. Meltzer, Hard Times for Unions: Another Look at the Significance of Employer Illegalities, 58 U. CHI. L. REV. 953, 1006-08 (1991).

31. See Blanchflower \& Freeman, supra note 22, at 58-59.

32. See BLUESTONE \& BLUESTONE, supra note 3, at 60-79.

33. Skeptics might suggest that the experience of the steel and auto industries demonstrates how illusory were these union gains, because the high labor costs and greater workplace rigidity associated with collective bargaining may itself have led to hundreds of thousands of autoworkers and steelworkers becoming unemployed. However, the similar unhappy fate of nonunion employees in the computer manufacturing industry a decade later indicates that the true explanation is major shifts in consumer demand in these product markets to which management was unable to adjust effectively - in both IBM and GM.

34. See, e.g., Leo Troy, Market Forces and Union Decline: A Response to Paul Weiler, 59 U. CHI. L. REV. 681, 683-84 (1992) (listing manufacturing industries such as automobile, steel \& clothing).

35. Unlike most unions which have experienced a decline in union growth during the last decade, the National Education Association (NEA) has enjoyed a 22\% membership growth between 1981 and 1991; similar trends have been experienced by the American Federation of Teachers (AFT) (37\% growth); American Federation of State, County, and Municipal Employees (AFSCME) (29\%) and Service Employees International (SEI) (67\%). See Peter Nulty, Look What the Unions Want Now, FoRTUNE, Feb. 8, 1993, at 130. 
has influenced firms' investment patterns, location decisions, compensation packages, and hiring policies. ${ }^{36}$

At its best, union avoidance takes the form of union substitution: the personnel department (now sporting the fancy sobriquet of "human resource management") assumes responsibility for finding out what benefits employees really want and which the firm can afford to provide. ${ }^{37}$ When such benign employer representation of employee interests works well, it looks a good deal more attractive than the stereotype of "Big Labor"-remote, bureaucratic organizations run by officials for their own, rather than their members', benefit. A large number of firms are not prepared, however, to leave the choice to their employees in this fashion. Instead, they engage in full-scale union suppression-firing employees who openly support union representation drives in nonunion workplaces, and permanently replacing employees who go on strike in support of collective bargaining in unionized workplaces. ${ }^{38}$ The success of the more benign employers' efforts at union avoidance is greatly enhanced by these "bare knuckles" tactics of their less scrupulous counterparts. Nonunion employees in this country are understandably reluctant to take chances with a statutory right whose exercise costs thousands of union supporters their jobs every year, whatever protection labor law might have promised them.

\section{The Rise of Employment Regulation}

The explanation for the decline in private sector collective bargaining is complex and multidimensional-a combination of union failings and employee attitudes, of employer action and legal inaction. But while the explanation may be obscure, the consequences of this decline are inescapable. Unions do not and will not represent the vast majority of employees. ${ }^{39}$ This raises the question of what, if anything, will replace unionism.

American legislators have answered this question by passing laws which directly regulate various aspects of the employment relationship. By sharply expanding the reach and intensity of employment regulation over the last thirty years, they have helped to fill the vacuum left by the decline of collective

36. See generally THOMAS A. KOCHAN ET AL., THE TRANSFORMATION OF AMERICAN INDUSTRIAL RELATIONS 93-108 (1986).

37. Id. at $47,62-65$.

38. See Paul C. Weiler, Hard Times for Unions: Challenging Times for Scholars, 58 U. CHI. L. REV. 1015, 1019-21 (1991) (citing statistics supporting the presence of employer resistance to union representation). But see LaLonde \& Meltzer, supra note 30, at 955-56 (arguing that observers have overestimated "the frequency with which employers violate their duty to bargain").

39. Predictions for future union density usually rely on past and current trends of union membership decrease, while calculating the natural rate of attrition, and sectorial growth or contraction. Yet, even if we take on an optimistic view and predict, for example, a $50 \%$ growth, membership will still cover only a fraction of the workforce (18\%, rather than the current $12 \%$ of the private sector). 
bargaining. ${ }^{40}$ This trend began with civil rights and fair employment laws in the 1960's, and was followed in the early 1970's by programs to protect occupational safety and health and the security and value of retirement pensions. Though the Reagan administration temporarily halted this trend in the federal legislative and executive branches, ${ }^{41}$ the focus of legal activity was by then shifting to the courts, partly through judicial fashioning of new rights through "interpretation" of old statutes (e.g., reading freedom from sexual harassment into Title $\mathrm{VI}^{42}$, and partly through wrongful dismissal litigation which made major inroads upon the employer's prerogatives under traditional at-will employment. ${ }^{43}$ Then, in the late 1980's and early 1990's, Congress returned to the fray by strengthening the Civil Rights $\mathrm{Act}^{44}$ and by passing the far-reaching Americans With Disabilities Act. ${ }^{45}$

On the surface, the regulatory model enjoys certain advantages over collective bargaining. Workplace regulation addresses each specific issue-such as the use of lie detector tests on the job ${ }^{46}$-on its intrinsic merits, rather than allowing the matter be swept aside in favor of the "bread and butter" issues that tend to dominate the final stages of labor-management negotiations. Moreover, as regulation addresses an issue, it defines rights (e.g., gender equality) in terms of moral and legal principles that apply to every employment relationship, regardless of the relative bargaining power enjoyed by employees in different workplace settings. Regulation gives the individual worker a personal right to enforce the employer's obligation in front of the appropriate tribunal, rather than having to depend on the good will and resources of the bargaining agent for the overall unit, who is constrained only by a vague union duty of fair representation. ${ }^{47}$

In practice, though, government regulation also displays characteristic failings. Inflexible administrative directives and unpredictable jury verdicts saddle business with considerable expense for defending personnel practices. ${ }^{48}$

40. See Clyde Summers, Effective Remedies for Employment Rights: Preliminary Guidelines and Proposals, 141 U. PA. L. REV. 457 (1992) (providing comprehensive survey of present-day employment regulation and insightful analysis of scope and limits of its enforcement).

41. See WeILER, GoverNing THE WORKPLACE, supra note 1 , at 24-25.

42. See Meritor Sav. Bank v. Vinson, 477 U.S. 57, 63-67, 73 (1986).

43. For more on the evolution of judicial remedies against unjust dismissal, see generally JAMES N. Dertouzos \& LYNN A. KAROLY, LABOR-MARKet RESPONSES TO EMPLOYER LIABILITY (1992) (concerning the expansion and economic impact of wrongful dismissal liability).

44. See Civil Rights Act of 1991, Pub. L. 102-166, 105 Stat. 1071 (1991).

45. See Americans With Disabilities Act of 1990, Pub. L. 101-336, 104 Stat. 327 (1990).

46. See Employee Polygraph Protection Act of 1988 \$\$ 2-10, 29 U.S.C.A. \$\$ 2001-2009 (1992).

47. These regulatory virtues are especially attractive to the legal mind. Wrongful dismissal litigation (under either state tort and contract law or federal civil rights law) has become a major growth industry over the last two decades. See DERTouzos \& KAROLY, supra note 43, at 4-16; John J. Donohue III \& Peter Siegelman, The Changing Nature of Employment Discrimination Litigation, 43 STAN. L. REV. 983, 986 (1991) (in particular, Figure 2 comparing growth of employment discrimination suits and other civil litigation filed in federal courts from 1970 through 1989).

48. See WEILER, GovERNING THE WORKPLACE, supra note 1, at 80-81; Donohue \& Siegelman, supra note 47 , at 983 . 
Too often, regulation does not afford beneficiaries enough gain to offset this expense. This is particularly true with respect to ordinary nonunion employees who cannot draw upon the expertise and protection of union officials to deal with bureaucracies administering such complex programs as OSHA and ERISA, and whose individual lawsuits for being fired from a low-paying job do not have the potential value likely to attract top litigators. ${ }^{49}$ Increasingly ambitious civil rights laws have performed a valuable role in giving collegeeducated blacks and women a fair chance at securing scarce but lucrative upper level positions. Nevertheless, these laws proved to be a frail reed of support for young blacks and women who left high school in the 1980's looking for reasonably well-paying, challenging, and secure jobs. ${ }^{50}$

The underlying problem with employment regulation is that neither government bureaucrats nor courtroom lawyers can effectively represent the interests of ordinary workers while they are on the job. While either a legislature or a court may proclaim substantive rights from outside the firm, meaningful enforcement of such rights requires that individuals take advantage of their rights through an independent and cohesive employee base within the firm. ${ }^{51}$

\section{REBUILDING THE STRUCTURE OF EMPLOYEE REPRESENTATION}

Needless to say, the solution to many employment problems is a flourishing economy that produces attractive job opportunities for those workers who are inevitably dislocated when the economy responds to changing consumer tastes. But as Professors Getman and Marshall develop throughout their article, ${ }^{52}$ rather than an economy that provides plenty of hours for people

49. See WEILER, GOVERNING THE WORKPLACE, supra note 1, at 81-82. For comparisons of regulatory standards enforcement in union and nonunion settings, see Robert J. Rabin, The Role of Unions in the Rights-Based Workplace, 25 U.S.F. L. REV. 169, 218-42 (1991); David Weil, Enforcing OSHA: The Role of Labor Unions, 30 INDUS. REL. 20 (1991).

50. See MISHEL \& BERNSTEIN, supra note 6, at 171, 206-09; John Bound \& Richard Freeman, What Went Wrong? The Erosion of Relative Earnings and Employment Among Young Black Men in the 1980's, 107 Q. J. OF ECON. 201 (1992) (finding that noncollege educated black men have suffered greater decline in real wages, compared to their college educated counterparts); June O'Neill, The Wage Gap Between Men and Women in the United States, WOMEN'S WAGES: STABILITY AND CHANGE IN SIX INDUSTRIALIZED COUNTRIES, 3 INT'L REV, OF COMP. PUB. POL'Y 353, 355 (Steven Willborn ed., 1991) (finding that while the gender wage gap has been somewhat narrowed, factors such as lower level of education and an accumulated loss of market skills affect women more than men).

51. An apt illustration is the plant closing law enacted in 1988-the Workers' Adjustment and Retraining Notification Act (WARNA)-with its mandatory 60-day notice of large-scale layoffs. WARNA can play the limited role of alerting nonunion employees of the need to start looking for other jobs. But unorganized, unrepresented employees are hardly able to pursue the legislation's broader ambition that the parties devise constructive alternatives to the employer's plan, whether a modest worksharing plan or a fullblown employee buy-out. Moreover, as a recent General Accounting Office (GAO) survey shows, only 1 in 5 workers actually gets notified prior to being laid off. The small fraction of employees who even enjoy this limited legal protection is attributed to both statutory exemptions, and employers' noncompliance. See Barbara Presley Noble, Notice On Layoffs Undercut, GAO Says, NEw YORK TIMES, Feb. 25, 1993, at D6.

52. See Getman \& Marshall, supra note 2, at 1812-15, 1872-75. 
to work at lower and lower rates of pay, we need an economy whose institutional framework induces employers and employees to cooperate in a high-value model of both worker performance and worker pay.

Are there changes in the law that might incline American industry in that direction? It is likely that the combination of a Democratic President and a Democratic Congress will elicit a long laundry list of reforms advocated by unions and other groups representing the interests of employees. Given the scarcity of political resources that policymakers can invest in labor law reform, we suggest two priorities, one short-term, the other for the longer run. Like Getman and Marshall, ${ }^{53}$ we believe that immediate legislative action should be taken to repair the key shortcoming in the NLRA: that it does not effectively protect employees from loss of their jobs as retaliation for exercising their long-established rights to unionize. Rather than focusing only on comprehensive labor law reform, however, we believe that policymakers should also tackle the longer-range goal of developing an additional option for worker representation - one that may be better attuned to the needs and desires of significant numbers of employees in the workplace of the twenty-first century.

\section{A. Labor Law Reform}

On its face, the NLRA promises employees that they have the right to join a union and to engage in concerted activity (i.e., to strike) for purposes of free collective bargaining. ${ }^{54}$ Employers are formally prohibited from discharging or otherwise discriminating against their employees for exercising these statutory rights. Nearly sixty years after the NLRA was enacted, however, thousands of employees are still illegally fired every year for participating in union organizing drives, ${ }^{55}$ in part because employers know that, at worst, the NLRB will give them a tap on the wrist if unfair labor practice charges are filed and proved. ${ }^{56}$ Thousands more workers lose their jobs if, like the paperworkers in Jay, Maine, they dare to go on strike in search of a better deal. The law characterizes this employer action as legal permanent replacement, rather than illegal dismissal, of the striking employees. ${ }^{57}$ The target of labor law reform should be to cure these glaring obstacles to

53. See Getman \& Marshall, supra note 2, at 1882-94.

54. National Labor Relations Act § 7, 29 U.S.C. § 157 (1992).

55. See Weiler, supra note 38.

56. See generally Paul Weiler, Promises to Keep: Securing Workers' Right to Self-Organization Under the NLRA, 96 HARV. L. REV. 1769, 1771-86 (1983) [hereinafter Weiler, Promises to Keep]; WEILER, GOVERNING THE WORKPLACE, supra note 1, at 225-241.

57. See generally Paul Weiler, Striking a New Balance: Freedom of Contract and the Prospects for Union Representation, 98 HARV. L. REV. 351, 382-404 (1984) [hereinafter Weiler, Striking a New Balance]; WEILER, GOVERNING THE WORKPLACE, supra note 1, at 261-273. 
employees' right not to forfeit their jobs by exercising rights supposedly guaranteed them by law.

Consider the problem of permanent replacement, as Getman and Marshall urge us, not from the point of view of company or union but from that of the individual employee. The law tells employees that they have an affirmative right to strike to use as the crucial lever for resolving deadlocks in our system of free collective bargaining. The statute explicitly states that while workers are on strike they remain employees of the firm. ${ }^{58}$ The Supreme Court even has said that striking employees must refrain from actions that might damage the product or reputation of the firm in the longer run, because labor law seeks to strengthen the "cooperation, continuity of service and cordial contractual relation between employer and employee that is born of loyalty to their common enterprise." ${ }^{59}$ And yet, under current law, if employees choose to go on strike, their employer can immediately and permanently replace them. ${ }^{60}$

It took the Supreme Court thirty years from the casual dictum in Mackay Radio $^{61}$ to figure out what tangible difference there might be between firing and permanently replacing a striker. The law now permits employees for some time after their strike is ended to return to work if and when vacancies open up. ${ }^{62}$ But for employees who may have spent twenty years with the company building up a stake of experience and seniority that can rarely be duplicated elsewhere, the stark reality is that if they do go on strike, they can be replaced by the company with people who in less than twenty minutes on the job gain permanent priority over the striking veterans. As the Jay paperworkers learned to their regret, the Supreme Court pictures a strike not as a protected right, but as a gamble with one's job-the most valuable asset that most employees possess. $^{63}$

Consider how this jurisprudential treatment of a supposed employee right would look in the context of modern employment regulation, particularly of wrongful dismissal. Suppose, for example, that an older worker sues for loss of his job and is met with the defense that he was only permanently replaced, not discharged. The employer's lawyer would likely face Rule 11 sanctions from the court for making such a frivolous legal argument. A difference between the two situations, of course, is that strikers, unlike older workers, voluntarily leave their jobs vacant, and thus the employer needs to fill them if it wants to keep operating. But should an employer be entitled to fill the jobs

\footnotetext{
58. National Labor Relations Act § 2(3), 29 U.S.C. $\$ 157$ (1989).

59. NLRB v. Int'l Bhd. of Elec. Workers Local 129, 346 U.S. 464, 472 (1953).

60. See NLRB v. Mackay Radio and Tel. Co., 304 U.S. 333, 345-46 (1938) (finding that NLRA does not require employers to dismiss replacements when strikers elect to return to work).

61. Id. at 333.

62. See NLRB v. Fleetwood Trailer Co. 389 U.S. 375, 380-81 (1967).

63. See Trans World Airlines v. Independent Fed'n of Flight Attendants, 489 U.S. 426, 438 (1989) ("We see no reason why those employees who chose not to gamble on the success of the strike should suffer the consequences when the gamble proves unsuccessful.").
} 
permanently for this temporary purpose? Consider the case of a pregnant woman who has left her job vacant to have her baby. It would be unthinkable to interpret an affirmative legal right to pregnancy leave as permitting the employer to replace the woman permanently and only banning her "discharge." Furthermore, the odds of a permanently replaced pregnant woman being able to find a job opening with the firm reasonably soon after the baby's delivery are likely far greater than the odds faced by a large number of strikers who leave their jobs and are replaced en masse.

The standard reaction of employers to this employment law analogy is that we simply cannot afford to give that kind of full-blooded force to the right of unionized employees to strike, because this would unduly tilt the balance of power in favor of labor. Management representatives regularly intone that employers must have the freedom to do what is necessary to fend off the pressures of a strike; thus employers need to be able to operate struck plants in order to resist the union's demands. ${ }^{64}$ Employers claim that to attract replacements they need to be able to offer them permanent priority over the strikers when the work stoppage ends. The employers claim that this is why we must retain this drastically diluted version of employees' right to strike without fear of losing their jobs.

None of the three steps in this employer argument is valid, at least as a generalization. There is ample evidence that employers do not need the carrot of "permanent" status to be able to recruit replacements. That evidence can be found in the case of lockouts under current U.S. law, where only temporary replacements are permitted, ${ }^{65}$ in the case of strikes under Canadian law, where no more than temporary replacement is allowed, ${ }^{66}$ and in the case of strikes in this country before the 1980's, where those employers who wanted to win the strike but not get rid of their union typically sought to hire only temporary replacements. ${ }^{67}$

This extensive comparative experience refutes the tacit assumption of the Mackay doctrine that employers always, or even usually, must be able to guarantee replacements a permanent position in order to recruit them during a strike. ${ }^{68}$ It is likely, though, that without this inducement some employers

64. Management's position has been well represented by Sen. Orrin Hatch during the Congressional debate over the issue of strike replacements. See, e.g., 138 CoNG. REC. S7765-73 (daily ed. June 10, 1992) (statement of Sen. Hatch).

65. See International Bhd. of Boilermakers, Local 88 v. NLRB, 858 F.2d 756, 762-64 (D.C. Cir. 1988); Operating Eng'rs Local 825 y. NLRB, 829 F.2d 458, 462-63 (3rd Cir. 1987).

66. See WeIleR, Governing THE WorkPLACE, supra note 1 , at $265-269 \& \mathrm{nn} .36,46$.

67. Charles R. Perry et al., Operating During Strikes: Company Experience, NLRB Policies and Governmental Regulations, in 23 LABOR RELAMIONS AND PUBliC POLICIES SERIES 63-66 (1982). For a compilation of other studies on the use of permanent replacements in the United States, see 137 CoNG. REC. H5534-35 (daily ed. July 17, 1991) (statement of Rep. Ford).

68. Indeed, as Getman and Marshall describe, the "permanence" offered by employers such as International Paper at Jay is a legally ephemeral status, at best. This is a result of the Supreme Court's decision in Belknap, Inc. v. Hale, 463 U.S. 491, 504 n.8 (1983) (describing replacements as permanent employees despite implicit condition that employers might decide or be ordered to rehire old workers). See 
might not be able to find all the people they need to operate the plant at the level they want. However, employers should not have the right to take every step they feel is necessary to win a bargaining struggle against the other side, any more than unions have such a right. For example, the NLRA forbade the strikers and their union at Jay from disciplining fellow paperworkers who went to work across the picket line, and forbade them to ask unionists elsewhere to refuse to handle the struck product flowing out of the International Paper facilities that were manned by these replacements. ${ }^{69}$ The law believes that the values infringed by such striker action outweigh the employees' claim to a better chance at winning the economic battle against their employer. That same priority should be given to the claim of legal strikers to be able to return to their jobs once the work stoppage is over, whoever may have won at the negotiating table. ${ }^{70}$

In contrast to management rhetoric, giving strikers that longer-range employment protection by no means gives them the upper hand in the immediate bargaining context. A strike is a two-edged sword. If a strike shuts down the employer's operation, it exerts pressure on management to compromise at the bargaining table; but by leaving employees out of work and without a regular paycheck, it puts corresponding pressure on their union to be equally receptive to ways of breaking the bargaining deadlock. Indeed, strikers typically experience far more disruption in their lives from loss of a paycheck than do shareholders faced with a potential cut in the company's quarterly dividend. That disparate impact is especially likely in the case of large firms, such as International Paper, whose other plants, both nonunion and union, may be running at full bore to fill the orders of customers normally supplied from the struck plant. Employers who are prepared to live with the union, but only on a reasonable economic footing, can function perfectly well without the right to hire permanent strike replacements, as is seen in the case of lockout replacements. It is only employers who want to get rid of the union, or at most deal with a "paper" union, who need Mackay Radio to serve that strategy.

Permanent striker replacement is the most visible and contentious issue on the current agenda for labor law reform. Yet it is part of a larger policy theme-that of protecting employees against loss of their jobs in retaliation for exercising the rights promised by the NLRA. More legal teeth must be provided to the remedies available for union supporters who are illegally fired during representation campaigns in nonunion firms. Just as happened in Mackay Radio, in the early years of the NLRA, the Supreme Court put a highly restrictive gloss on Board remedies by limiting the size of monetary

Weiler, Striking a New Balance, supra note 57, at 392, n.138 (describing how tenuous permanent status is for replacement employees after Belknap).

69. See Weiler, Striking a New Balance, supra note 57, at 394-404 (criticizing contemporary law on union discipline of replacements and secondary boycotts).

70. Id. at $394-404$ 
awards to the net back pay lost by the employee. The resulting average award of approximately $\$ 2,500$ per firing helps explain why there has been a steep increase in unscrupulous employers' use of this weapon to suppress unions. ${ }^{71}$ By contrast, under contemporary antidiscrimination legislation and wrongful dismissal litigation, there is broad consensus in favor of substantial monetary awards (including explicitly punitive damages) against firms that fire employees in contravention of public policy. ${ }^{72}$ It is high time, then, that we applied that same principle to the remedies available under the NLRA-the legal pioneer in prohibiting firings for "bad reasons."

\section{B. Beyond Labor Law Reform}

After these innovations are made to the core weakness in our national labor law (ineffectual protection of employees against loss of their jobs for exercising their statutory rights) the new Administration may be best advised to leave the rest of the NLRA alone. Adding even more regulatory provisions-including such favored union proposals as access to employer premises during organizing drives or an expanded scope of the duty to bargain ${ }^{73}$ - to a federal law which already intrudes too far into the representation campaign and negotiating disputes, might simply elicit new managerial tactics in union suppression and would reinforce unions' reliance on the already overburdened NLRB. ${ }^{74}$ Once employees have been guaranteed effective protection of their jobs against employer retaliation for supporting a union, it then should be up to the union movement to take the steps necessary to earn and retain that employee support.

Unquestionably, unions in the United States face a stiff challenge. To attract the allegiance of new members, unions must win some major victories

71. See Weiler, Promises to Keep, supra note 56, at 1780 (presenting statistical evidence of increase from 1957 to 1980 in numbers of workers reinstated after unfair employer intimidation); WEILER, GOVERNING THE WORKPLACE, supra note 1, at 232-249; Summers, supra note 40, at 477-479 (explaining why back pay remedy is inadequate deterrent to violations).

72. See supra note 47. For more on the discrepancy between the law on wrongful dismissal of nonunion members and that of union members, see generally Katherine Van-Wezel Stone, The Legacy of Industrial Pluralism: The Tension Between Employment Rights and the New Deal Collective Bargaining System, 59 U. CHI. L. REV. 575, 605-16 (1992) (charting differing rights of union and nonunion workers due to preemption of state law rights by $\$ 301$ of Labor Management Relations Act).

73. See, e.g., Julius G. Getman, Ruminations on Union Organizing in the Private Sector, 53 U. CH. L. REV. 45, 70-71 (1986); Charles B. Craver, The National Labor Relations Act Must Be Revised to Preserve Industrial Democracy, 34 ARIZ. L.R. 397, 417-37 (1992); .

74. We do not mean to imply that nothing else in the NLRA merits reform. We have focused here on the most pressing labor law issues-protecting employees from loss of their jobs for exercising their legal right to support the cause of unionism in a representation campaign or a strike. Next, we will sketch the case for longer-term development of an alternative form of employee representation. Here we note that possibility of middle-range reform, which would reconstruct (rather than directly regulate) the labormanagement relationship through such devices as instant certification elections and employee boycotts of struck products. See WEILER, GOVERNING THE WORKPLACE, supra note 1, at 252-61, 269-73, for the arguments in favor of each. 
over recalcitrant employers that advance the strongly-felt views of current members. But to lessen managerial paranoia about collective bargaining-and, hopefully, reduce the intensity of their union avoidance efforts-unions must also demonstrate a willingness to move away from traditional contract patterns and work rules. Unions must accommodate firms' need for organizational and financial flexibility in the more demanding economic environment in which business now operates.

Fortunately, a growing body of experience demonstrates that union leaders can navigate that delicate path between the needs of their members and those of their employers. As Getman and Marshall's article points out, ${ }^{75}$ new conceptions of workplace organization emphasize meaningful employee participation as a key to enhanced labor productivity. Firms must be able to tap the insights and ingenuity of seasoned front-line employees in developing new methods of making products that are both cheaper and of higher quality. Recent scholarship indicates that unionism can actually enhance the necessary levels of cooperation and teamwork on the part of employees. ${ }^{76}$ This scholarship shows that collective bargaining provides a context in which firms can make a credible commitment to employees that if they work smarter, not just harder, they can be assured of both a fair share of immediate gains from production innovations and long-term employment (though not necessarily job security) even after both sides have figured out ways to economize on the use of labor.

Nevertheless, while we have reason to hope for a revival of the American labor movement (particularly under the umbrella of a reformed NLRA), we should not delude ourselves that more than a modest fraction of American workers will have access to collective bargaining in the foreseeable future. As we have stated, private sector unionism is low and declining. ${ }^{77}$ Furthermore, the Electromation ${ }^{78}$ decision noted earlier casts a cloud over steps taken by some nonunion employers to devise worker involvement programs that give their employees influence not only over the firm's production process, but also over their own employment conditions.

75. See Getman \& Marshall, supra note 2, at 1810-11.

76. See BLUESTONE \& BlUESTONE, supra note 3, at 169-86; Adrienne E. Eaton \& Paula B. Voos, Unions and Contemporary Innovations in Work Organization, Compensation, and Employee Participation, in UNIONS AND ECONOMIC COMPETTTIVENESS 189-94 (Lawrence Mishel \& Paula B. Voos eds., 1992); Maryellen R. Kelley \& Bennett Harrison, Unions, Technology, and Labor-Management Cooperation, in UNIONS AND ECONOMIC COMPETITIVENESS 276-77 (Lawrence Mishel \& Paula B. Voos eds., 1992); Thomas A. Kochan \& Robert McKersie, Human Resources, Organizational Governance, and Public Policy: Lessons from a Decade of Experimentation in TRANSFORMING ORGANIZATIONS 180-81 (Thomas A. Kochan \& Michael Useem eds., 1992); David Levine \& Laura Tyson, Participation, Productivity, and the Firms' Environment, in PAYING FOR PRODUCTIVITY: A LOOK AT THE EVIDENCE 230-31 (Alan Blinder ed., 1990).

77. See supra notes $26-29$ and accompanying text.

78. Electromation, Inc. and Teamsters Local 1049, No. 25-CA-19818, 1992 WL 386692 (N.L.R.B. Dec. 16, 1992). 
The argument of management spokesmen against the use of Section 8(a)(2) of the NLRA, in cases like Electromation, is that the law should not require employees "to check their brains at the front door when they come to work."79 Employers fervently hope their supporters in the courts or Congress will eliminate what they consider a misguided use of the law's traditional ban on "company unionism."

We are inclined to proceed even further towards that destination, but following quite a different path. We do not assume that labor law's traditional adversarial posture is entirely anachronistic, as do those who romantically postulate that, in a free market, there will only be cooperative relations between employers and employees. This notion too quickly glosses over the inevitable conflict as well as complementarity of interests between labor and capital. Indeed, the same people who celebrate "participatory management" on behalf of employees are horrified at the thought of a "unionized management" shaping the course of the firm and outcomes for shareholders. ${ }^{81}$ Thus, while we are inclined to repeal rather than simply retrench upon Section 8(a)(2), we would do so only as part of a broader recasting of the labor laws that makes it just as easy for employees to enjoy independent representation, if that is what they prefer. $^{82}$

With respect to those employees who do not want to join a union, we recommend that the law-instead of regulating from the outside more and more aspects of the employment relationship-create a new alternative to union representation in which employees represent themselves on the job. Every American workplace above a certain size (say, for example, 25 or 50 employees) should have an "Employee Participation Committee" (EPC) that voices the interests of employees in dealings with senior management about a wide range of employment issues.

One of us has developed elsewhere the detailed case for this EPC concept. $^{83}$ Suffice it here to say that committee members elected by both office and plant employees would have the right to be consulted before

79. See Daily Lab. Rep. (BNA) No. 157, at G-1 (Aug. 14, 1991); Daily Lab. Rep. (BNA) No. 173, at A-5 (Sept. 6, 1991).

80. See Steve Gunderson, NLRB Muddies Regulatory Waters, WALL ST. J., Feb. 1, 1993, at A10; Gunderson Seeks Management Consensus on Legislation to Overrule Electromation, Daily Lab. Rep. (BNA) No. 17, at A-4 (Jan. 28, 1993); Charles W. Baird, Are Quality Circles Illegal?: Global Competition Meets the New Deal, 18 CATO INST. BRIEFING PAPERS 9-10 (1993).

81. Cf. ChaRles C. HeCKSCHER, THE NEW UNIONISM: EMPLOYEe INVOLVEMENT IN THE ChaNGing CORPORATION 85-113 (1988) (arguing that many companies that encourage extensive worker participation in decisionmaking nontheless are antiunion because unions, by their very nature, oppose power with power").

82. Certainly one should not give employers an unfettered prerogative to determine whether and how employees will be involved in firm decisionmaking without at the same time retrenching upon the current managerial exclusion from the NLRA-a judge-made doctrine that denies collective bargaining rights to a growing number of employees who exert only a modest influence upon employer policy (often only as part of a group, rather than individually). See David M. Rabban, Distinguishing Excluded Managers from Covered Professionals Under the NLRA, 89 COLUM. L. REV. 1775, 1787-92 (1989).

83. See WEILER, GOVERNING THE WORKPLACE, supra note 1, at 282-295. 
management could make material changes in workplace conditions (e.g., the introduction of new technology or the adoption of health care cost containment programs). Every EPC would be entitled to the relevant information necessary for performing its representational role on behalf of employees, analogous to the data that management now provides to boards of directors representing shareholders. The committee also would be entitled to a level of financial resources-contributed jointly by the firm and employees according to a statutory per capita formula-so that the committee could draw on the advice of people and organizations with experience and expertise in relevant subject matters. ${ }^{84}$ For larger firms with numerous committees representing employees at multiple locations, a "federal structure" 85 to the EPC would ensure that firms take account of the interests of various groups in decisions that affect the broader enterprise. In order to ensure the representational value of these committees, elections of representatives would be conducted through a secret ballot process, and committee members would be protected from employer reprisals for defending the interests of fellow workers.

This brief sketch shows how the EPC model could provide a home-grown form of employee representation that is quite different from (though not incompatible with) what is now provided by labor unions and employment lawyers. A host of technical questions have to be confronted before the idea can be seriously entertained. ${ }^{86}$ Fortunately, we can draw upon considerable experience in this country with voluntary programs of employee involvement, and in other countries that have mandated such participation by law (most prominently, West Germany, whose workplace performance ranks high in both productivity and equity). ${ }^{87}$ However, as introducing a statutory model of EPC's would involve a major change in the industrial system of the United States, we suggest three incremental modes of implementation. Gradual experimentation with EPC's can provide a period of adjustment, assessment of their merits, and an opportunity to refine the structure of EPC's and the optimal role of the federal and state governments in mandating them.

84. A prominent source of such assistance would likely be the trade union in that industrial sector, but so also would women's action committees, injured worker groups, and the like. Where a union already enjoyed bargaining rights in a workplace, elected employee-officials of the local union would function as the EPC, with the same responsibility and resources to represent the interests of their fellow unit members.

85. In multisite enterprises, an "enterprise EPC" would be established, composed of representatives from the plant-level EPC's. The enterprise EPC would coordinate and set, on some issues, broad guidelines to the operations of the local committees.

86. These include, for example, structuring the appropriate remedies for situations of noncompliance; defining the relationship between collective bargaining and the EPC in unionized settings; providing a manageable set of regulations dealing with elections of representatives, financing, and the opening of information channels; and defining the appropriate role of the EPC in administering regulated legal policies and the scope of issues over which the committee will have consultative rights.

87. See KathleEN THELEN, UNION OF PARTS: LABOR POLITICS IN POSTWAR GERMANy 1-5 (1991) (attributing West Germany's continued equity and productivity growth to country's centralized collective bargaining and its dual statutory system for plant labor representation through works councils, which are formally separate from unions). 
One place to begin in the aftermath of Electromation is by amending section 8(a)(2) of the NLRA to allow nonunion employers who want to experiment with employee participation to do so only if they comply with minimum standards of employee representation. These would include, as previously outlined, use of secret ballot elections, provision of information and financial resources, and protection of representatives from reprisal. Only those employers whose voluntary representation plans satisfy those conditions would be protected from unfair labor practice charges of "domination or interference."

A second path for gradual implementation would be to mandate employee committees whose primary responsibility would be to administer the growing number of workplace regulatory programs. The law has already intervened to enforce employee rights to safe and healthy workplaces, to establish freedom from sexual harassment, and to protect workers from wrongful dismissal. These laws should now invite employees, not just government bureaucrats and company managers, to confront the challenge of implementing such rights effectively for the intended beneficiaries, but not counterproductively for the common enterprise. ${ }^{88}$

Finally, a place to begin with respect to employee influence over nonlegal issues is the health care sector. The verdict in the 1992 presidential election made it clear that policymakers must do something to stem spiraling health care costs and thereby provide relief to government budgets and employer payrolls. The burden of such cost containment will be borne by health care employers and employees in much the same way that employers and employees have experienced belt-tightening and dislocation in the automobile, airline, and computer industries. ${ }^{89}$ It is crucial that we involve a broad cross section of health care workers-not just high-priced doctors, but also nurses, technicians, and support staff-in figuring out ways to deliver high quality medical care more economically. The danger of relying solely upon top-down management of the health care problem is that we may sacrifice not simply the welfare of employees, but also the lives of patients.

88. This was the approach taken in the Comprehensive Occupational Safety and Health Reform Act that was introduced in the 102d Congress. See H.R. 3160, 102d Cong., 1st Sess. $\$ 201$ (1991); S. 1662, 102 d Cong., 2d Sess. $\$ 201$ (1992). The bill mandated establishment of joint safety and health committees in every workplace of more than 10 employees. While the proposal had little chance of enactment in 1992 in the face of opposition from President Bush, its prospects are considerably rosier under the Clinton Administration.

It is noteworthy that a major source of Republican resistance was the antiunion sentiment of American business. Employers worried that giving workers some experience with independent representation of their interests in this limited sphere might encourage many to explore the idea of broad-ranging collective bargaining. Remarkably, the congressional committees eventually acceded to management's request by deleting any suggestion that employees select their representatives by secret ballot election. See S. REP. No. 453, 102d Cong., 2d Sess. 25-29 (1992); H.R. REP. No. 663, 102d Cong., 2d Sess. 56 (1992).

89. Although health care has been one of the economy's fastest-growing sectors in terms of employment, the new Administration's promise to contain spiraling health care costs inevitably implies cutbacks in jobs and benefits for ordinary health care workers, not just high-priced physicians. See Mary A. Grayson, What Organized Labor Wants, 67 J. AM. HosP. Ass'N 26 (Jan. 5, 1993). 


\section{CONCLUSION}

We must face the challenge of improving both productivity and equity in the workplace. The evidence from the last two decades is that these objectives are not mutually exclusive. Employers and employees must cooperate in a host of innovative measures to improve the performance and competitiveness of American industry. However, employees will engage in such cooperation only if they are confident that they will be treated fairly in the process. Employee participation committees provide ordinary workers a modest but guaranteed voice about both production of output and distribution of the firm's equity. The employees in many firms will be satisfied with the level of influence secured through this new institutional framework for the labor market. Other employees, disenchanted with a management they realize does not listen to their committee representatives, can use the EPC as a platform from which to pursue the greater clout that comes from representation by a full-blown labor union. At least this will be true if the union movement makes itself more inviting to unorganized workers, and if the labor laws are reshaped to make employee exercise of this promised legal right a less fearful experience than it now is. 
